\title{
DIE AANLEIDING TOT EN ENKELE IMPLIKASIES VAN DIE DESIMALISASIE VAN DIE SUID-AFRIKAANSE GELD. STELSEL
}

\section{Inleiding.}

Gedurende die afgelope Parlementsitting is die Wet op Desimale Munt aangeneem, wat voorsiening maak vir die oorskakeling van die Unie se huidige geldstelsel na 'n desimale stelsel, en wel vanaf 14 Februarie 1961. 'n Desimaliseringsraad, met dr. E. H. D. Arndt, Onderpresident van die Reserwebank, as voorsitter, is ingestel om toesig te hou oor die tegniese aspekte van die oorskakeling.

Soos reeds bekend sal die Rand (R) (gelyk aan die huidige tiensjielingeenheid) die hoofeenheid wees, met die sent (C) as die ondergeskikte eenheid (100 sent is gelyk aan 1 Rand en 10 sent gelyk aan die waarde van die huidige sjieling). Verder sal breuke van die sent, naamlik $\frac{1}{2}$ sent en $\frac{1}{4}$ sent, as erkende eenhede beskou word. Die Wet maak verder voorsiening vir die uitgifte van twee goue munte met waardes van $R 2$ en R1, vyf silwermunte met waardes van $50,20,10,5$ en $2 \frac{1}{2}$ sent onderskeidelik en drie bronsmunte met onderskeidelike waardes van 1 , $\frac{1}{2}$ en 'n 1 sent. $\mathrm{Na}$ alle verwagting sal die nuwe brons- munte dieselfde grootte en gewig hê as die huidige bronsmunte met slegs 'n wysiging in die kleur en ontwerp. So ook word verwag dat slegs die waardeaanduidings op die nuwe silwermunte sal verander, en nie die ontwerp nie. Die aanduiding „2s" op die tweesjielingstuk sal hiervolgens vervang word met „20c", op die trippens $2 \frac{1}{2} \mathrm{c}$, op die sikspens ,5c", op die sjieling ,10c", ens. Waarskynlik sal die nuwe desimale note van presies dieselfde grootte en ontwerp wees as die note wat tans gebruik word. Aanduidings wat tans 10/-, $£ 1, £ 5$ en $£ 10$ is, sal dan aangepas word om ekwivalente waardes in terme van die Rand aen te dui.

Alvorens aandag geskenk word aan enkele van die vernaamste implikasies wat hierdie oorskakeling teweegbring, is dit van belang om kortliks te let op die faktore wat aanleiding gegee het tot die desimalisasie van ons geldstelsel.

2. Geskiedkundige agtergrond.

Die desimale stelsel het reeds in die 17de eeu 'n definitiewe vorm begin aanneem, maar 'n volledige stelsel is eers 
teen die einde van die 18de eeu uitgebou. So anvaar die V.S.A. die desimale geldstelsel tussen die jare 1786 en 1792, en dit word gevolg deur Kanada, Frankryk, die ander lande van die Latynse Muntverbond, Duitsland, die Skandinawiese lande, Oostenryk, Hongarye, Rusland, Sjina, Japan, die Brits-Oos-Afrikaanse gebiede en Indië, terwyl gerugte daarop dui dat Australië en Nieu-Seeland ook binnekort sal oorskakel. Indien laasgenoemde twee gebiede daartoe oorgaan, sal Engeland die enigste land van belang wees wat die stelsel ven f.s. en d. sal besit. Maar ook hier is die behoefte aan oorskakeling reeds gevoel, en onlangs is oorgegaan tot die stigting van "The British Association Metric Committee" om verslag te doen oor die uitvoerbaarheid, implikasies en koste verbonde aan die desimalisering van mate, gewigte en munte.

Uit beskikbare bronne blyk dat desimale geldstelsels in 145 gebiede of lande dwarsdeur die wêreld bestaan en dat hiervan nie minder as 138 tweedesimale stelsels is nie. Die enigste drie-desimale stelsels blyk te bestean in: Cyprus, waarvan die pond verdeel is in 1,000 mil; Irak, waarvan die dinar verdeel is in 1,000 fil; Israel, waarvan die pand verdeel is in 1,000 prutah; Jordaan, waarven die dinar verdeel is in 1,000 fil; Libië en Egipte, waarvan die pond verdeel is in 1,000 milliemes en 100 piastres; Soedan, waar die Egiptiese stelsel tot 1957 bestaan het, toe dit deur 'n soortgelyke Soedanese stelsel vervang is.
Wat Suid-Afrika betref, dateer die desimalisasie uit die jare 1932, toe 'n wetsontwerp te dien effekte deur mnr. N. C. Havenga, destydse Minister van Finansies, ingedien is. Die tweede lesing van hierdie wetsontwerp is vir 7 April 1932 bepaal maar is deur 'n sameloop van omstandighede nie vir die tweede maal gelees nie, en hierdie saak het onaangeroer gebly tot die jare 1943 '45, toe die Raad van Handel en Nywerheid besig was met 'n ondersoek hoofsaaklik betreffende die probleem van naoorlogse heraanpassing van nywerhede en ekonomiese heropbou in die algemeen. As gevolg van 'n ondersoek ook na die vraagstuk van die rasionalisering van die Suid-Afrikaanse nywerheid het die Raad teenoor die kwessie van standaardisering te staan gekom, en alhoewel sy hoofbelangstelling mate en gewigte was, het dit ook die onderwerp van die muntwese ingesluit. Op grond van hierdie ondersoek is aanbeveel dat „die Regering, tesame met die Regerings van die Britse Gemenebes en die Verenigde State van Amerika, die invoering van die metrieke muntstelsel, gewigte en mate in oorweging neem".

In 1944 het die Nasionale Bewaringsen Antiverkwistingsorganisasie, wat tydens die oorlog in die lewe geroep is, by minister J. H. Hofmeyr, die destydse Minister van Finansies en Onderwys, daarop aangedring dat die menings van verteenwoordigende openbare liggame in die Unie oor die moontlikheid van desimalisering van ons geldstelsel, mate en gewigte ingewin moet word. Op 15 Junie 1945 is deur die Minister hiertoe magtiging verleen en 'n komitee van 
ondersoek, met mnr. J. T. Becklake, voormalige Direkteur van die Suid-Afrikaanse Munt is tot voorsitter benoem.

$\mathrm{Na}$ 'n ondersoek van sowat twee en 'n half jear bevind die Becklakekomitee dat 'n duidelike meerderheid van persone wat geraadpleeg is, ten gunste van die desimalisasie is en wel omdat dit (a) 'n eenvoudiger en vinniger metode van berekening sal meebring; (b) 'n akkurater en effektiewer metode van kosteberekening en prysvasstelling inhou; (c) 'n maklik versteanbare metode van berekening van monetêre transaksies beteken en (d) 'n besparing van tyd in onderwysinrigtings sal meebring.

Die Komitee se opdrag was nie slegs tot die desimalisering van die Unie se muntstelsel beperk nie maar het ook mate en gewigte ingesluit. In hierdie verband word dan ook aanbeveel „dat geen stappe in verband met die desimalisasie van Suid-Afrika se gewigte en mate op die huidige tydstip gedoen moet word nie, behalwe om hulle, sover prakties moontlik, te vereenvoudig en te korreleer met die standaarde van gewigte en mate in ander lande".

Op grond van hierdie aanbevelings versoek die Minister van Ekonomiese Sake die Raad van die Suid-Afrikaanse Buro vir Standaarde in 1949 om die werk van die Becklakekomitee voort te sit. $\mathrm{Na}$ 'n grondige ondersoek doen die Komitee ven die Suid-Afrikaanse Buro vir Standaarde in Junie 1954 aan die Minister van Ekonomiese Sake verslag, waaruit blyk dat die 10s.-sentstelsel as basis behoort te dien van enige toe- komstige Sufd-Afrikaanse desimale muntstelsel.

In Januarie 1956 dien mnr. P. A. Moore, L.V. vir Kensington, sy wetsontwerp in tot reèling van die gangbaarheid van geld, die muntwese en wettige betaalmiddele en daarmee in verband staande sake, wat die aanbevelings van die Buroverslag vervat. Hieruit het voortgevloei die samestelling van 'n kommissie in Augustus 1956 bestaande uit 'n voorsitter, dr. N. Diedericks, tans Minister van Ekonomiese Sake, en 14 lede, om ondersoek in te stel en verslag te doen oor ${ }^{1}$ ):

„(1) Die desimale muntstelsel wat hy na oorweging van die voor- en nadele van die verskillende moontlike desimale stelsels as die geskikste vir die Unie beskou.

(2) Die manier warop die aanbevole stelsel ingevoer moet word ten einde die koste van oorskakeling en die ontwrigting aan die ekonomie gedurende die oorgangstydperk sover doenlik te beperk.

(3) Die beraamde koste van vervanging van boekhou- en soortgelyke masjiene asook ander koste verbonde aan die oorskakeling op die veronderstelling dat die nuwe stelsel op die aanbevole wyse ingevoer word.

(4) Die mate waarin en die grondslag waarop vergoeding ten opsigte van die koste van oorskakeling deur die Staat betaal moet word, indien die beginsel van vergoeding deur die Regering aanvaar word. 
(5) Ander praktiese aspekte van oorskakeling na 'n desimale stelsel wat nie hierbo genoem is nie".

Hierdie ondersoek is na twee jaar voltooi en aan die begin van September 1958 aan die Regering voorgelê. $\mathrm{Na}$ volledige bespreking in die Senaat en die Volksraad word die Wet op Desimale Munt, 1959 in 'n Buitengewone Staatskoerant van 3 Junie 1959 geproklameer, en dit maak voorsiening vir 'n muntstelsel vir die Unie op 'n desimale grondslag en vir daarmee in verband staande aangeleenthede. Onlangs is die oorskakelingsdatum op Dinsdag, 14 Februarie 1961 bepaal, en 20 maande daarna d.w.s. in Oktober 1962, moet die oorskakelingsproses voltooi wees.

\section{Enkele van die vernaamste} implikasies.

Aangesien die Wet op Desimale Munt die desimalisasie van ons geldstelsel 'n voldonge feit gemaak het, is dit nou nie meer gepas om oor die wenslikheid al dan nie van hierdie stelsel uit te wei nie. Wanneer die krediet- en debetsy van oorskakeling teenoor mekaar gestel word, tree een belangrike aspek na vore, en dit is dat die onkoste van oorskakeling redelikerwys onmiddellik bereken kan word maar dat die voordele, hoofsaaklik oor die langtermyn moeilik in klinkende munt berekenbaar is.

Die vernaamste voordele verbonde aan die desimale muntstelsel of Randsent-stelsel kan kortliks soos volg saamgevat word: a. 'n besparing van tyd en arbeid (volgens 'n groot masjienmaatskappy sal desimalisasie van die muntstelsel 'n besparing van 15 persent in masjientyd alleen teweegbring); b. besigheidsmetodes sal vereenvoudig en vaartbelyn wees; c. die aantal dokumente wat nodig is, sal verminder word; d. ouditering sal gouer en makliker gaan; e. berekenings sal in die algemeen vereenvoudig wees: $f$. rekenmasjiene sal goedkoper wees omdat die Unie toegang sal hê tot 'n groter wêreldmark vir standaard monetêre masjiene.

Alhoewel heelwat meer oor elke voordeel uitgebrei kan word, is dit van belang om kortliks ook te wys op enkele van die vernaamste oorskakelingsprobleme wat teen hierdie voordele afgeweeg moet word. Dit spreek immers vanself dat die uitwerking van die invoering van 'n nuwe geldstelsel revolusionêr is weens die aanpassing van nuwe by vorige waardes. Hoewel die probleem wat hiermee saamhang, deur die aanvaarde Rand-sent-stelsel heelwat vergemaklik word, moet egter nie uit die oog verloor word nie dat binne afsienbare tyd afgewyk gaan word van die f.s.d.-stelsel, wat meer as 'n eeu lank in gebruik is. As gevolg van hierdie aanpassingsprobleme het die Desimale Muntkommissie dan ook aanbeveel „dat die invoering van die nuwe stelsel deur 'n voorbereidingstydperk voorafgegaan moet word waarin die publiek oor die implikasies van die verandering opgevoed kan word en die handel, nywerheid, finansies, publieke en ander administrasies hulself daarvoor kan voorberei"')).

Wanneer bedink word dat die British Royal Commission on Decimal Coin.age in 1920 ten opsigte van desimalisasie in die Verenigde Kontnkryk met sy homo- 
gene en geletterde bevolking gevrees het vir sosiale ontwrigting, word besef dat Suid-Afrika, met sy heterogene en relatief ongeletterde Bantoebevolking's), waarvan 'n klein gedeelte die gevorderde ruilekonomie van 'n moderne nywerheidstaat aangeneem het, wel probleme kan ondervind. Hierdie probleme kan egter in ' $n$ groot mate opgelos word deur die Departemente van Bantoeonderwys en Bantoe-administrasie en -ontwikkeling, wat deur middel van die bestaande media, naamlik ,6,000 skole en 24,000 onderwysers wat vir $1,200,000$ kinders voorsiening maak; 150 departementele en distriksamptenare; 500 landbou-amptenare; 200 erkende stamhoofde; 3,600 skoolkomitees met 36,000 lede en omtrent 300 skoolrade met 3,500 lede"/4), sowel as amptelike publikasies, koerante en die Bantoe-uitsaaidiens, die oorgrootste gedeelte van die bevolking kan bereik.

Die oorskakeling sal ook belangrike reperkussies op die gewone opvoedkundige programme hê, waar minder klem op die bestaande stelsel en meer op die nuwe gelê sal moet word en hersiening van sillabusse en skoolboeke vereis word. Vir hierdie aanpassing, onder andere, is die voorbereidingstydperk van twee jaar gestel.

Verder is die moontlikheid van 'n geringe inflasionistiese uitwerking nie uitgesluit nie, veral ten opsigte van goedere en dienste wat minder as 1/kos en waar die verskaffers in 'n hoë mate monopolistiese mag uitoefen. Die rede hiervoor lê opgesluit in die feit dat $10 c=1 /-$, terwyl onder die huidige stelsel $12 \mathrm{~d} .=1 /-$; m.a.w. $1 \mathrm{c}=1.2 \mathrm{~d}$., wat die sent dus 20 persent meer werd maak as die pennie. 'n Dosie vuurhoutjies of „pennielekkers" wat vandag 1d. kos, kan byvoorbeeld vir 1c verkoop word, wat dan 'n verlies van 20 persent vir die verbruiker inhou. Die saak kan weer reg gestel word deur die dosie vuurhoutjies groter en die pennielekker groter en soeter te mak.

As gevolg van die lewendige mededinging in die Suid-Afrikaanse handel sal hierdie probleem van uitbuiting van die verbruiker deur die wette van handelswedywering opgelos word, en dit is onwaarskynlik dat die verbruiker skade sal ly, behalwe in die geval van monopolistiese leweransiers, oor wie die owerheid noukeurig toesig sal hou. Ingeval hierdie verskynsel nie die hoof gebied kan word nie, sal die lewensduurte nie in dieselfde mate beïnvloed word nie, aangesien niemand sy inkomste slegs aan artikels en dienste met waardes van minder as 1/- bestee nie.

Benewens die voorafgaande byna hoofsaaklik sosiale implikasies van oorskakeling is dit ook belangrik om vervolgens te let op die meer berekenbare kosteaspek. In hierdie verband wys die Verslag van die Desimale Muntkommissie daarop dat die beraamde bruto kompensasiebetalings en ander uitgawes deur die staat soos volg sal wees ${ }^{5}$ ):

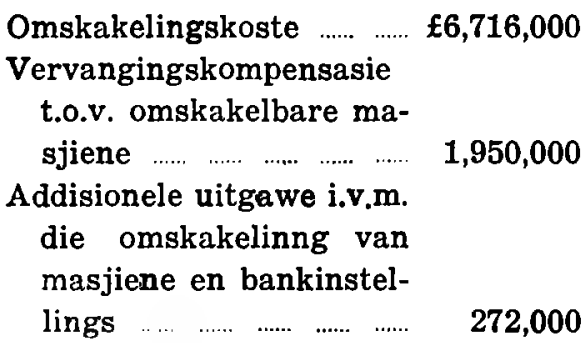
KOERS 
Betaling aan die masjienma:atskappye vir hulle administratiewe dienste in verband met die betaling van vervangingskompensasie

Tentatief beraamde administratiewe en ander uitgawe van die staat ${ }^{6}$ )

Totaal 200,000 $\overline{\mathfrak{9}, 171,000}$

Beraam word dat die netto koste vir die staat in die afwesigheid van belangrike loon- en prysskommelinge sowat $£ 8,967,000$ sal beloop, aangesien 'n bedrag van ongeveer $£ 112,000$ op Suidwes-Afrika verhaal sal word en $£ 92,000$ in die vorm van doeaneregte op masjiendele wat vir die omskakelingsprogram nodig sal wees. In verband met die staatsuitgawe van ongeveer $\mathfrak{f}, 000,000$ beveel die Kommissie aan dat dit oor die volgende vier jaar versprei moet word:

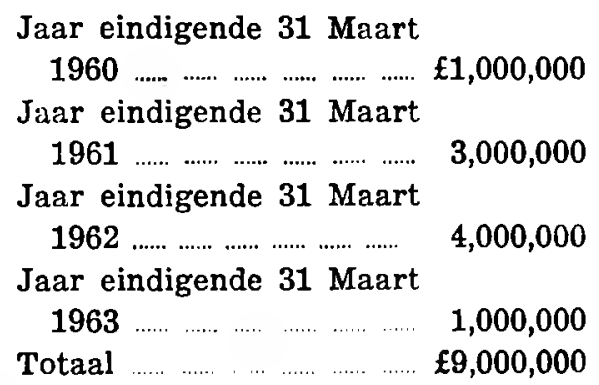

\section{Slot.}

As die bostaande oorwegings in oënskou geneem word, dan blyk dat die omskakeling van masjiene die grootste en moeilikste, veral geldelike, aspek van die invoering van die desimale geldstelsel is. Die $\mathfrak{£} 9,000,000$, wat as die moontlike omskakelingskoste gestel word, lyk op die oog af 'n groot bedrag; maar, hierdie opoffering moet gesien word teen die onskatbare voordele op die lang duur sowel as 'n staatinkomste van so-

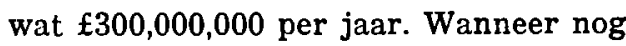
verder in aanmerking geneem word dat die eersgenoemde bedrag oor 'n periode van vier jaar versprei word, vorm dit inderdaad maar 'n nietige deel van die staatsbegroting.

Die feit dat die wêreldtendens in die rigting van desimalisasie is, is een van die sterkste bewyse dat die ekonomiese voordele van die oorskakeling na die desimale stelsel die onmiddellike koste daarvan oortref.

'n Algemeen erkende beleid in die sakewêreld is tog dat die noodsaaklike opofferinge van vandag ten voordele van die toekoms is.

P.U. vir C.H.O.

\section{P. ERASMUS.}

1) Verslag van die Desimale Muntkominissie, U.G. 35/1958, Die Staatsdrukker, pp. iii en iv.

2) U.G. $35 / 1958$, p.57.

3) In Mei 1958 het die destydse Departement van Naturellesake beraam dat sowat 40 persent van die Bantoebevolking geletterd was.

4) U.G. $35 / 1958$, p.70.

5) U.G. 35/1958, p. 103.

6) D.w.s. uitgawes van die Desimaliseringsraad en sy personeel; publisiteit en drukwerk; ontwerping van nuwe munte; addisionele onkoste van die Tesourie, ens. 